\title{
Rapid Detection of Phenol Constituents from Industrial Effluents Using Microbial Tyrosinase and Nanoparticles
}

\author{
Bi Bi Zainab*1 and Dayanand Agsar ${ }^{2}$ \\ ${ }^{1}$ Department of Microbiology, Jouf University, KSA \\ ${ }^{2} A-D B T$ Research Laboratory, Gulbarga University, India \\ *Corresponding author: Bi Bi Zainab Mazhari, Department of Microbiology, Jouf University, KSA
}

\begin{tabular}{|c|c|}
\hline ARTICLE INFO & ABSTRACT \\
\hline $\begin{array}{l}\text { Received: March 18, } 2019 \\
\text { Published: 幽 March 29, } 2019\end{array}$ & $\begin{array}{l}\text { Citation: Bi Bi Zainab, Dayanand Agsar. Rapid Detection of Phenol Constituents from In- } \\
\text { dustrial Effluents Using Microbial Tyrosinase and Nanoparticles. Biomed J Sci \& Tech Res } \\
\text { 16(4)-2019. BJSTR. MS.ID.002874. }\end{array}$ \\
\hline
\end{tabular}

\section{Opinion}

Environmental sensors are gaining importance because of ever- growing environmental concerns and their ability to provide rapid information on detection of toxic compounds especially phenols [1]. In particular, there is a great need for synthesis of systems for analysis and detection of phenolic compounds. Phenols are found in waste water of large number of industries [2]. Phenol and its derivatives which are carcinogenic and toxic, even at low concentrations are important pollutants [3]. Hence the development of analytical methods for determination and monitoring of phenols is necessity. In this context, enzymes are used for fast detection and screening of phenols. Among enzymes, tyrosinase is used for the detection of phenolic compounds and attracting great interest for fast and simple detection of phenols [4]. Tyrosinase is one of the metallic coppers containing protein and part of polyphenol oxidases and classified as monophenol, o-diphenol oxidoreductase with EC; 1.14.18.1. Its catalysis oxidation of phenols to orthoquinones, both in the presence of molecular oxygen [5,6]. These enzymes are widely distributed in nature (mammals, plants, bacteria, fungi and actinomycetes) [7]. Various spectrometric and chromatographic methods are in common use for phenol determination. Thus, biological active compound Streptomyces tyrosinase for phenol detection is the innovative idea to prevent the use of conventional methods [8,9]. The advantage of using enzymes as biological element for detection of phenols is it can bind to the substrate with great specificity and high selectivity $[10,11]$. The highest production of tyrosinase was achieved by Streptomyces
[12-15]. Thus this tyrosinase was used for the detection of phenols. Effect of $\mathrm{pH}$ and temperature on the detection process was also analyzed $[16,17]$. Phenolic solutions such as synthetic wastewater containing catechol, pyrogallol, resorcinol, P-nitrophenol were treated with tyrosinase at different concentration [18]. The total phenol assay was calorimetrically determined using 4-AAP method. The literature for detecting phenol using other enzymes takes $2 \mathrm{hr}$, whereas this enzyme detects the phenol with 10 mins $[19,20]$. This proves the potentiality of Streptomyces tyrosinase enzyme for detecting phenols.

\section{References}

1. F Naghibi, F Pourmorad, S Honary, M Shamsi (2003) Decontamination of water polluted with phenol using Raphanussativus Root. Iranian Journal of Pharmaceutical Research 2(1): 29-32.

2. C Hansch, S Mc Carns, C Smith, D Dodittle (2000) Comparative QSAR evidence for a free-radical mechanism of phenol-induced toxicity. Chem Biol Interact 127(1): 61-72.

3. M Laine, NK Jorgense (1996) Straw compost and bioremediated soil as inocula for the bioremedation of chlorophenol contaminated soil. Appl Environ Microbiol 62(5): 1507-1513.

4. VM Daskalaki, Z Frontistis, D Mantzavinos, A Katsaounis (2011) Solar light-induced degradation of bisphenol-A with TiO2 immobilized on Ti. Catalysis Today 161(1): 110-114.

5. KP Lisha, Anshup, T Pradeep (2009) Enhanced visual detection of pesticides using gold nanoparticles. J Env Sci Health Pesticides Food contaminants and agricultural wastes 44(7): 697-705.

6. Keisuke Ikehata, A James Nicell (2009) Color and toxicity removal following Tyrosinase-Catalyzed Oxidation of Phenols. Biotechnology Progress 16(4): 533-540. 
7. M El Shora, Hamed, Metwally (2008) Use of tyrosinase enzyme from Bacillus thuringiensis for the decontamination of water polluted with phenols. J Biotechnology 7(2): 305-310.

8. E Selinheimo, C Gasparetti, M Mattinen, CL Steffensen, J Buchert, et al. (2009) Comparison of substrate specificity of tyrosinases from Trichodermareeseiand Agaricusbisporus. Enzyme Microbial Technol 44(1): 1-10.

9. M Beatriz Serra, Dolores Morales, A Jinbiao Zhang, Julio Reviejo, H Elizabeth Hall, et al. (2005) In-a-Day Electrochemical Detection of Coliforms in Drinking Water Using a Tyrosinase Composite Biosensor. Anal Chem 77(24): 8115-8121.

10. DG Mita, A Attanasio, F Arduini, N Diano, V Grano, et al. (2007) Enzymatic determination of BPA by means of tyrosinase immobilized on different carbon carriers. Biosens Bio electron 23(1): 60-65.

11. S Chen, J Huang, D Du, J Li, H Tu, et al. (2011) Methyl Parathion Hydrolase Based Nanocomposite Biosensors for Highly Sensitive and Selective Determination of Methyl Parathion. Biosensors and Bioelectronics 26(11): 4320-4325.

12. M Xia, C Chen, M Long, C Chen, W Cai et al. (2011) Magnetically separable mesoporous silica nanocomposite and its application in Fenton catalysis. Micropor Mesopor Mater 145(1-3): 217-223.

13. CC You, A Verma, VM Rotello (2011) Engineering the nanoparticlesbiomacromolecule interface. Soft Matter 2: 190-204.

\section{ISSN: 2574-1241}

DOI: 10.26717/BJSTR.2019.16.002874

Bi Bi Zainab Mazhari. Biomed J Sci \& Tech Res

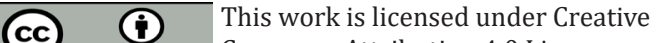

Submission Link: https://biomedres.us/submit-manuscript.php
14. O Kreft, M Prevot, H Mohwald, G Sukhorukov (2007) Shell-in-shell microcapsules: A novel tool for integrated, spatially confined enzymatic reactions. Angw Chem Int Ed 46(29): 5605-5608.

15. SJ Ramiz, Alkasir, Maryna Ornatska, SilvanaAndreescu (2012) Colorimetric Paper Bioassay for the Detection of Phenolic Compounds. Anal Chem 84(22): 9729-9737.

16. GY Kim, MS Kang, J Shim, SH Moon (2008) Substrate bound tyrosinase electrode using gold nanoparticles to pyrroloquinoline quinone for a pesticide biosensor. Sens Actuators B Chem 133(1): 1-4.

17. GY Kim, J Shim, MS Kang, SH Moon (2008) Preparation of a highly sensitive enzyme electrode using gold nanoparticles for measurement of pesticides at the ppt level. J Environ Monitor 10(5): 632-637.

18. GY Kim, J Shim, MS Kang, SH Moon (2008) Optimized coverage of gold nanoparticles at tyrosinase electrode for measurement of a pesticide in various water samples. J Hazard Mater 156(1-3): 141-147.

19. JC Vidal, S Esteban, J Gil, JR Castillo (2006) A comparative study of immobilization methods of a tyrosinase enzyme on electrodes and their application to the detection of dichlorvos organophosphorus insecticide. Talanta 68(3): 791-799.

20. Bi Zainab Mazhari, Dayanand Agsar, MVN Ambika Prasad (2017) Development of paper biosensor for the detection of phenol from industrial effluents using bioconjugate of Tyr-AuNps mediated by novel isolate Streptomyces tuirus DBZ39. Journal of nanomaterials.

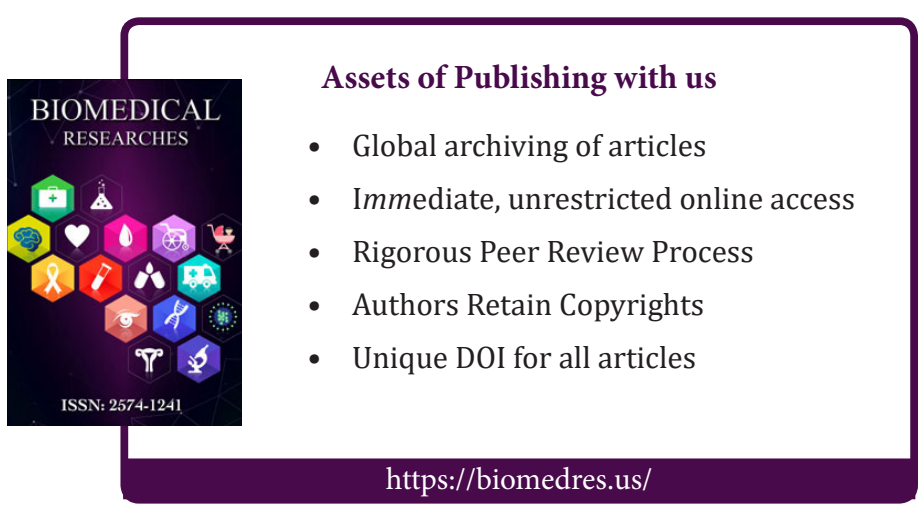

